\title{
Conformance Test of Association Among Several Arbuscular Mycorrhizal (AM) to the Growth of Coffea Arabica (Coffeae arabica L.) Seedling
}

\author{
Indra Dwipa ${ }^{1}$, Pajri Ananta Yudha ${ }^{2}$ \\ ${ }^{1}$ Department of Agronomy, Faculty of Agriculture, Andalas University, Padang, West Sumatera, Indonesia. \\ ${ }^{2}$ Department of Plant Protection, Faculty of Agriculture, Andalas University,Padang, West Sumatera, Indonesia.
}

\begin{abstract}
The research was conducted in green house and Agronomy Laboratory, Department of Agronomy, Faculty of Agriculture, Andalas University, Padang Indonesia from August to Desember 2015. The research aimed to study and obtain the conformance of several Arbuscular mycorrhizal (AM) to coffea arabica growth. Completely Randomized Design (CRD) was used in this research with 5 treatments and 4 replications. The data analyzed by Duncan's New Multiple Range Test with the real level 5\%. The treatments were without AM, $5 \mathrm{~g}$ Glomus sp. inoculant per polybag, $5 \mathrm{~g}$ Glomus manihotis per polybag, $5 \mathrm{~g}$ Acaulospora heterogama per polybag, $5 \mathrm{~g}$ Gigaspora rosea per polybag. The result showed all of AM inoculants influenced the plant height, seedling dry weight and fresh weight of seedling and significantly different to the percentage of AM infection to plant root.
\end{abstract}

Keywords: Arbuscular Mycorrhizal, Coffeae arabica L.

\section{Introduction}

Coffee is the most consumed beverage in the world and the demand of coffee increases every year (Kitzberger et al. 2013). Coffee plant has a shallow tap root and nearby to the soil surface. The root of coffee less developed and causes the nutrients absorption less efficient. In order to increase the efficiency of nutrient absorption by roots, the certain way required (Laderach et al. 2006).

Arbuscular Mycorrhiza (AM) is one of fungi can increase the growth and development including production of plant (Breullin et al. 2010). In several researches, AM can take nutrient from unreached area in the soil. It is caused by the external hyphae of AM is small in size and can take nutrients from micro pores of soil (Chen et al. 2010). The information of association among plant root and AM is still limited, and recently the suitable AM inoculants to seedling of coffee Arabica, the more information of the association among AM and coffee plant is important to study this relationship. The research aimed to study the association of several AM to the coffee plant growt

\section{Materials and Method}

\subsection{Time and Place}

The research was conducted in green house and Agronomy Laboratory, Department of Agronomy, Faculty of Agriculture, Andalas University, Padang Indonesia from August to Desember 2015. 


\subsection{Method}

Completely Randomized Design (CRD) was used in this research with 5 treatments and 4 replications. The total of trial unit were 20 and each trial consisted of 4 polybag and 2 polybag taken as sampling. The treatments were $\mathrm{A}=$ without treatment; $\mathrm{B}=5 \mathrm{~g}$ inoculant of Glomus sp/polybag); $\mathrm{C}=5 \mathrm{~g}$ inoculant of Glomus manihotis/ polybag; $\mathrm{D}=5 \mathrm{~g}$ inoculant of Acaulospora heterogama/polybag and $\mathrm{E}=5 \mathrm{~g}$ inoculant of Gigaspora rosea/polybag. The data further analyzed by F test and continued by Duncan's Multiple Range Test (DNMRT) in significant level $5 \%$

\subsection{Treatment}

Ultisol soil used in this research. The soil sterilized from weed, dirt and mashed with sieve sized $2 \mathrm{~mm}$. 500 $\mathrm{g}$ soil taken randomized and $\mathrm{pH}, \mathrm{P}, \mathrm{Cu}, \mathrm{Zn}$ and $\mathrm{Al}-\mathrm{dd}$. The soil sterilized by electric oven in $150^{\circ} \mathrm{C}$ for 1,5 hour and thereafter put on polybags. The 2 months after planting seedling (m.a.p) used in this research. AM inoculant put in $5 \mathrm{~cm}$ under soil surface. Each polybag planted 1 seedling. The homogeny seedling chosen in this treatment. Watering, weeding, tilling the soil, fertilizing and controlling pests and diseases conducted in this research.

The parameter observed were length of stem seedling, length of tap root, plant fresh weight, plant dry weight, percentage of AM infection to seedling root. The length of tap root measured in 16 w.a.p and the total of leave wide/ seedling measured in the last observation. The observation of plant fresh weight conducted in the last observation and then followed by the observation of plant dry weight by the plants put in electric oven and heated in $70^{\circ} \mathrm{C}$ for 48 hours. The canopy ratio : root measured after the dry weight measured. The infection of AM to root measured by :

$$
\text { Percentage of root infected by Am }=\frac{\text { Total of roots infected }}{\text { Total of roots observed }} \times 100 \%
$$

\section{Result and Discussion}

\subsection{Stem Growth of Seedling}

The growth of seedling observed by giving several AM inoculants to Coffee Arabica seedling in 16 w.a.p showed that there was no significant different among treatments (Table I).

TABLE I. The Stem Height Growth of Coffee Arabica Seedling in 16 W.A.P By Giving Several AM Inoculants

\begin{tabular}{|c|c|c|c|}
\hline \multirow{2}{*}{ AM inoculants } & \multicolumn{3}{|c|}{ Height of stem seedling (cm) } \\
\cline { 2 - 4 } & Early & Last & Accretion \\
\hline Acaulospora heterogama & 6,20 & 10,74 & 4,54 \\
\hline Wiithout AM inoculant & 6,10 & 10,45 & 4,35 \\
\hline Glomus manihotis & 6,30 & 10,03 & 3,73 \\
\hline Gigaspora rosea & 6,30 & 9,80 & 3,50 \\
\hline Glomus sp. & 6,20 & 9,53 & 3,33 \\
\hline \multicolumn{4}{|c}{ Diversity coefficient $=45 \%$} \\
\hline
\end{tabular}

Environmental and biotic factor are the factors influence the plant growth (Puspitasari et al 2012). Table I. showed that giving of several AM inoculants didn't affect the growth of Coffee arabica seedling. It caused by the influence of AM was still not seen in short time. Feldmann et al. (2009) stated that generally in first year of coffee showed the slow growth and Hoeksema et al. (2010) stated that for plantation crops, the influence of AM will be seen in after 6 months. 


\subsection{The Length of Tap Root}

The length of tap root observed in 16 w.a.p and the result shown in Table II.

TABLE II. Length of tap root of Coffe Arabica in 16 w.a.p by giving several AM inoculants

\begin{tabular}{|c|r|}
\hline AM inoculants & Length of tap root (cm) \\
\hline Glomus manihotis & $15,91 \quad$ a \\
\hline Without inoculant & 15,33 a \\
\hline Gigaspora rosea & 11,96 a \\
\hline Glomus sp. & $9,73 \quad$ b \\
\hline Acaulospora heterogama & $7,18 \quad \mathrm{~b}$ \\
\hline \multicolumn{2}{|c|}{} \\
\hline \multicolumn{2}{|c|}{ Diversity coefficient $=24,6 \%$}
\end{tabular}

The AM inoculants infected the plant started from roots (Smith and Read 2008). Table II showed that giving Glomus sp., without inoculant and Gigaspora heterogama were the best treatments for length of tap root than the others treatments. The biotic factor such as genetic influenced the length of tap root (Smith and Read 2008). The difference of genetic each inoculant also influenced the length of tap root (Nusantara 2012 et al. 2012). The length of tap root caused by the difference of tap root length each plant (Chen et al. 2010). Schubler and Walker (2010) also stated that in early stage of root growth, there was cell division and cell growth and caused elongation of root. Sidqui and Kataoka (2011) added that the cell enlargement cause the elongation of root in plant.

\subsection{Fresh Weight of Plant}

Fresh weight of plant observed in 16 w.a.p and the result showed that there was no different among several treatments to fresh weight (Table III). AM inoculant as line with vegetative growth. The better vegetative growth caused higher of fresh weight of plant (Smith and Read 2008). Nusantara et al. (2011) stated that fresh weight was a represented of nutrients in plant tissue with water content.

TABLE III. Fresh Weight of Coffee Arabica Seedling in 16 W.A.P By Giving Several AM Inoculants.

\begin{tabular}{|c|c|}
\hline AM inoculants & Fresh weight $(\mathrm{g})$ \\
\hline Acaulospora heterogama & 3,71 \\
\hline Without inoculant & 3,15 \\
\hline Glomus manihotis & 2,81 \\
\hline Gigaspora rosea & 2,78 \\
\hline Glomus sp. & 2,54 \\
\hline \multicolumn{2}{|c|}{ Diversity coefficient $=51,00 \%$} \\
\hline
\end{tabular}

\subsection{Dry weight of plant/seedling}

Dry weight of plant/seedling also observed in 16 w.a.p and there was no different among the treatments (Table IV). Table IV showed that all treatments didn't influence the dry weight of plant. In this case, there was no good association among AM inoculants with plant root. Siddiqui and Kataoka (2011) stated that it caused by the carbohydrate and nutrients in plants. Oehl et al. (2009) stated that high and low of nutrients content in plant body can be seen in dry weight of plant. Nusantara et al. (2011) added that the effectiveness of AM can be seen by increasing of dry weight of plant. 
TABLE IV. Dry Weight of Coffee Arabica Seedling in 16 W.A.P by Giving Several AM Inoculants.

\begin{tabular}{|c|c|}
\hline AM inoculants & Dry weight $(\mathrm{g})$ \\
\hline Acaulospora heterogama & 0,85 \\
\hline Glomus manihotis & 0,73 \\
\hline Without AM inoculants & 0,72 \\
\hline Gigaspora rosea & 0,71 \\
\hline Glomus sp. & 0,61 \\
\hline \multicolumn{2}{|c|}{ Diversity coefficient $=46,1 \%$} \\
\hline
\end{tabular}

\subsection{Percentage of AM Infection to Plant Root}

The percentage of AM infection to root observe in 16 w.a.p and the result shown in Table V.

TABLE V. Percentage of AM infection in 16 w.a.p by giving several AM inoculants.

\begin{tabular}{|c|c|cc|}
\hline \multirow{2}{*}{ AM inoculants } & \multicolumn{3}{|c|}{ Percentage of AM infection to root (\%) } \\
\cline { 2 - 4 } & Origin data & $\begin{array}{c}\text { Data transformed to } \\
\operatorname{arc~} \sin \sqrt{x}\end{array}$ \\
\hline Acaulospora heterogama & 24,50 & $30,95 \quad \mathrm{a}$ \\
\hline Glomus sp & 9,50 & $17,00 \quad \mathrm{~b}$ \\
\hline Gigaspora rosea & 9,50 & $16,80 \quad \mathrm{~b}$ \\
\hline Glomus manihotis & 9,00 & $16,55 \quad \mathrm{~b}$ \\
\hline Without inoculant & 2,50 & 6,13 & $\mathrm{c}$ \\
\hline \multicolumn{2}{|c|}{ Diversity coefficient $=37,3 \%$} \\
\hline
\end{tabular}

Table $\mathrm{V}$ showed that all inoculants can infect the plant root. But the infectivity level is different each other. Acaulospora heterogama infection was higher than other treatments. It caused by 'enhancement of photosynthesis in coffee plant and cause the enhancement of exudates of plant root. The enhancement of plant ot will increase of AM growth and infection of AM increases (Vosatka and Albrechtova 2009). Vogelsang and Bever (2009) said that the conformance of mycorrizhal inoculated to plant will determine the association among plant seedling and symbiotic fungi. Seedling were not given AM inoculants also showed the infection of AM. It caused by the seedling was infected by AM naturally in nursery (Smith and Read 2008). Symbiosis among AM and plant root is effective if AM can produce beneficial effect to the plant nor surrounding environment (Nusantara et al. 2012 ). Viewed from plant side, AM can be said effective by nutrient absorption, especially P, plant resistance to pest and disease and drought (Nusantara et al. 2012). Viewed by environmental side, AM inoculants can be said effective if they can changed the growth medium, for example water aggregate (Nusantara 2011). Rillig and Mummey (2006) added that water aggregate formed by glomalin compound produced by fungi. Effective inoculants in colonizing the root are potential as good inoculant (Nusantara et al. 2011). Effectiveness of AM depends on environmental and biological factors, especially phosphorus level in soil, genera of AM (Nusantara et al. 2012). Each genera has different infection and sporulation characteristic in different environment (Douds et al 2010).

\section{Conclusion}

Acaulospora heterogama was the best inoculant in infecting the root of Coffee Arabica with the percentage of infection was $24,50 \%$ in origin data and 30,95\% after transformed. There was no different among several Arbuscular mycorrhizal in stem growth of seedling, length of tap root, fresh weight and the dry weight of Coffe Arabica seedling. 


\section{Acknowledgements}

Thank very much for Dean of Agriculture Faculty, Andalas University who facilitated this research and all participants who helped for this research.

\section{References}

[1] A.D. Nusantara, Y.H. Bertham, I. Mansur. 2012. Working with Arbuscular Mycorrhiza. Seameo Biotrop. 82 p

[2] A.D. Nusantara, C. Kusmana, I. Mansur, L.K. Darusman, H. Soedarmadi . 2011b. Diameter and dose of vermicompost to determine inoculant production of arbuscular mycorrhiza and biomass of legume. Jpurnal of Biota. 16(1):1-9.

[3] A. Schüßler, C. Walker . 2010. The Glomeromycota. A Species List with New Families and New Genera. Kew: The Royal Botanic Garden Kew.

[4] C.S.G. Kitzberger, M.B.d. S. Scholz, L.F.P. Pereira, L.G.E. Vieira, T. Sera, J.B.G.D. Silva, M.d. T. B. Benassi. 2013. Diterpenes in green and roasted coffee of Coffea arabica cultivars growing in the same edapho-climatic conditions. Journal of Food Composition and Analysis. 30 : 52-57

https://doi.org/10.1016/j.jfca.2013.01.007

[5] D.D. Douds, G. Nagahashi , P.R. Hepperly. 2010. On-Farm production of inoculum of indigenous arbuscular mycorrhizal fungi and assessment of diluents of compost for inoculum production. Bioresour Technol. 101: 23262330

https://doi.org/10.1016/j.biortech.2009.11.071.

[6] D. Puspitasari, K.I. Purwani, A. Muhibuddin. 2012. Exploration of Indigenous Vesicular Arbuscular Mycorrhiza on Corn Field, Sampang Madura, East Java. Journal of Science and Art. 1: 19-22

[7] F. Breuillin, J. Schramm, M. Hajirezaei, A. Ahkami, P. Favre, U. Druege, B. Hause, M. Bucher, T. Kretzschmar, E. Bossolini, E. Kuhlemeier, E. Martinoia, P. Franken, U. Scholz, D. Reinhardt. 2010. Phosphate systemically inhibits development of arbuscular mycorrhiza in petunia hybrida and re-presses genes involved in mycorrhizal functioning. The Plant Journal. 64:1002-1017.

https://doi.org/10.1111/j.1365-313X.2010.04385.x

[8] F. Feldmann, I. Hutter, C. Schneider. 2009. Best production practice of arbuscular mycorrhizal inoculum. Soil Biol. 18:319-335.

https://doi.org/10.1007/978-3-540-95894-9_20

[9] F. Oehl, E. Sieverding, K. Ineichen, P. Mäder, A. Wiemken, T. Boller . 2009. Distinct sporulation dynamics of arbuscular mycorrhizal fungal communities from different agroecosystems in long-term microcosms. Agric Ecosyst Environm 134:257-268. https://doi.org/10.1016/j.agee.2009.07.008

[10] J.D. Hoeksema , V.B. Chaudhary, C.A. Gehring, N.C Johnson, J. Karst, R.T Koide, A. Pringle , C. Zabinski , J.D Bever, J.C. Moore, G.W.T. Wilson, J.N. Klironomos, J. Umbanhowar . 2010. A Meta-analysis of context-dependency in plant response to inoculation with mycorrhizal fungi. Ecol Lett. 13:394-407.

https://doi.org/10.1111/j.1461-0248.2009.01430.x

[11] K.M. Vogelsang, J.D. Bever. 2009. Mycorrhizal densities decline in association with nonnative plants and contribute to plant invasion. Journal of Ecology. 90:399-407.

https://doi.org/10.1890/07-2144.1

[12] M.C. Rillig, D.L. Mummey. 2006. Mycorrhizas and soil structure. New Phytol. 171:41-53. https://doi.org/10.1111/j.1469-8137.2006.01750.x

[13] M.M. Chen, H.B. Yin, P. O 'Connor, Y.S. Wang, Y.G. Zhu. 2010. C:N:P Stoichiometry and specific growth rate of clover colonized by arbuscular mycorrhizal fungi. Plant Soil. 326:21-29. https://doi.org/10.1007/s11104-0099982-4 
[14] M. Vosátka, J. Albrechtová. 2009. Benefits of arbuscular mycorrhizal fungi to sustainable crop production Berlin: Springer-Verlag. p. 205-224.

[15] P. Laderach, L Collet, T. Orberthur, J. Pohlan, 2006. Relationships between environmental factors and coffee cup quality in selected growing regions of Cauca, southern Colombia. In: 21st International Conference of Coffee Science, vol. 1, Montpellier, France, pp. 1-12.

[16] S.E. Smith, D.J. Read. 2008. Mycorrhizal Symbiosis. $3^{\text {rd }}$ ed. San Diego: Academic Press.

[17] Z.A. Siddiqui, R. Kataoka. 2011. Mycorrhizal inoculants: progress in inoculant production technology in I Ahmad, F. Ahmad, J. Pichtel. (eds.). Microbes and Microbial Technology: Agricultural and Environmental Applications. Springer Science+Business Media. New York: p. 489-506.

https://doi.org/10.1007/978-1-4419-7931-5_18 